\title{
EPHB3 Gene
}

National Cancer Institute

\section{Source}

National Cancer Institute. EPHB3 Gene. NCI Thesaurus. Code C24368.

This gene is involved in cell-cell adhesion and cellular aggreg ation and plays a role in tyrosine kinase signal transduction. 